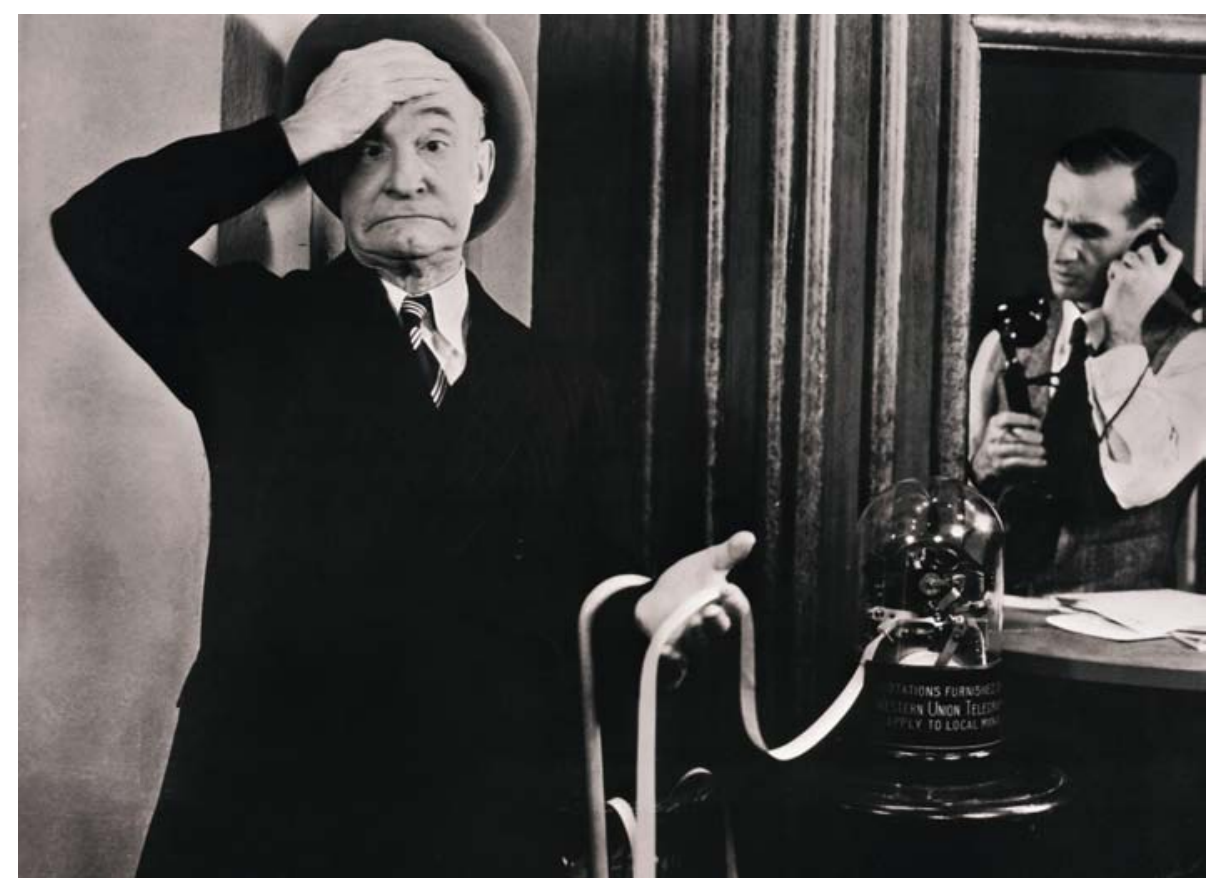

\section{Soberano susto}

Hacienda transformó rocas de cobre y molibdeno en papeles financieros que permiten hoy mantener en pie a nuestras vacas flacas. Se acumulan fondos soberanos (FEES y FRP) por 20.427 millones dólares (15\% del PGB).

La sensatez fiscal fue también amiga de la suerte. Justo cuando se había decido pasar un 35\% de los ahorros a activos más riesgosos, vino la debacle de septiembre de 2008 y todo quedó en nada. Así, Chile evitó una pérdida de capital de unos 1.900 millones de dólares. Por cierto fue una feliz lección de humildad (en finanzas es mejor, a veces, tener suerte que saber mucho).

Después del suertazo vino el susto. Las autoridades fiscales han mantenido todo empozado en renta fija (70\% en bonos soberanos y 30\% en mercado monetario). Ni hablar de diversificar inversiones hacia activos algo más riesgosos y rentables.

En mi opinión, esto es un error porque el horizonte de los fondos en cuestión es relativamente largo. Habría al menos tres razones para, pasado el golpe de fortuna, dejar el miedo y volver a la sensatez de incluir una proporción de activos de renta variable.

1) Incluso si pensamos en déficit fiscales abultados (3\% del PGB), la mayor parte de los FEES no necesitarán venderse rápido. El fisco ya retiró holgados 1.750 millones en 2009 y ha definido financiar parte de los déficit con emisión de deuda.

2) La primera línea de defensa de todo país frente a contingencias externas son las reservas internacionales del Banco Central. Hoy contamos con otros 24.209 millones dólares para financiar balanza de pagos. La cifra equivale a casi nueve meses de importación, holgura equivalente al triple del mínimo de lo que el mercado internacional considera prudente.

3) Mantener, como lo hace Chile, más de 6.000 millones de dólares en instrumentos ultra-líquidos del mercado monetario es una exageración cuando la liquidez interbancaria ha tendido a normalizarse en los mercados maduros. $\mathrm{El}$ exceso de liquidez no es gratis. El retorno es bajo y nos exponemos a pérdidas si suben las tasas largas.

En suma, pasado el susto y gozada la suerte, es hora de retomar el rumbo a un portafolio de ahorros más sanamente diversificado, uno que incluya acciones y papeles corporativos de riesgo moderado.

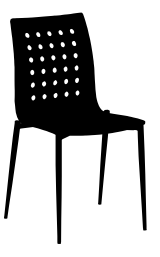

COLUMNA por Juan Foxley*

* Director del Diplomado de Finanzas UAH
Decano: Jorge Rodríguez Grossi.

Fono Facultad: 6920277

e-mail: jrodrigu@uahurtado.cl

economiaynegocios.uahurtado.cl/observatorio Producción OE: Comunicar, Escuela de Periodismo UAH.

$O E$ es una revista de circulación gratuita. 